\title{
Age related clinical presentation and laboratory parameters in juvenile SLE: a Hungarian multicenter study
}

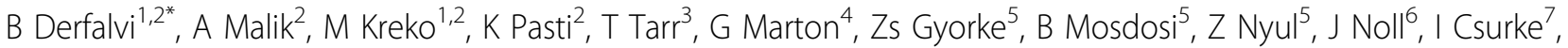 \\ F Harangi ${ }^{8}$, Zs Balogh ${ }^{9}$, I Orban ${ }^{9}$, K Sevcic ${ }^{9}$, E Kiss ${ }^{9}$, R Kaposzta $^{10}$, B Szucs ${ }^{11}$, S Turi ${ }^{11}$, P Sallay ${ }^{2}$, Gy Reusz ${ }^{2}$, \\ T Tulassay ${ }^{2}$, AJ Szabo ${ }^{2}$
}

From 18th Pediatric Rheumatology European Society (PReS) Congress

Bruges, Belgium. 14-18 September 2011

\section{Background}

Several studies on SLE suggest that age at onset modifies the expression of the disease in terms of clinical presentation, pattern of organ involvement and laboratory findings. There are only few data about the age-related differences within the pediatric SLE group.

\section{Aim}

To determine the different clinical manifestations and laboratory characteristics of juvenile SLE (jSLE) in the pre- and postpubertal age in patients fulfilling the 1997 ARA criteria for SLE.

\section{Methods}

Retrospective multicenter analysis of data of 77 jSLE patients, divided into two groups according to the age. Mean age at disease onset was $8.9 \pm 1.9$ (range 4-11y), follow-up period 7,1 $\pm 4.3 \mathrm{y}$ in the prepubertal $(\mathrm{n}=30)$, and $14.7 \pm 1.2$ (range 11-16y) follow-up period $6.0 \pm 4.3 \mathrm{y}$ in the postpubertal $(n=47)$ group. Various clinical and laboratory parameters were analysed and compared between groups.

\section{Results}

Female:Male ratio was 9:1 in both groups. The most common initial manifestations as butterfly rash occured in $60 \% / 62 \%$, cytopenias $60 \% / 57 \%$, kidney involvement $47 \% / 43 \%$, serositis $27 \% / 23 \%$, in the pre/postpubertal group. Arthritis was significantly more common in the

* Correspondence: derfalv@gyer1.sote.hu

${ }^{1}$ 2nd. Dept of Pediatrics, Semmelweis University Budapest

Full list of author information is available at the end of the article older group (57\%/77\%). General symptomes like fever $47 \% / 57 \%$, weight loss $23 \% / 30 \%$, increased infection rate $20 \% / 13 \%$ were also similar in the two age groups, as did ANA, anti-dsDNA, anti-Sm, anti-SSA, anti-SSB positivity and low C3 and C4 levels. Anti-RNP antibody was more common in the younger ages $(33 \% / 10 \%)$. Mean SLEDAI score was 12 in both groups. Zero SLICC damage index is significantly more common $(68 \% / 43 \%)$ in the older group after comparable follow-up period.

\section{Conclusion}

There are no prominent clinical differences except arthritis at onset and higher percentage of 0 SLICC damage score in older jSLE patients as compared to youngers.

\section{Author details}

${ }^{1} 2$ nd. Dept of Pediatrics, Semmelweis University Budapest. ${ }^{2} 1$ st. Dept. of Pediatrics, Semmelweis University Budapest. ${ }^{3} 3$ rd Department of Internal Medicine, University of Debrecen. ${ }^{4}$ BAZ County Teaching Hospital, Miskolc. ${ }^{5}$ Dept. of Pediatrics, POTE University of Medicine, Pecs. ${ }^{6}$ Heim Pal Childrens'Hospital, Budapest. ${ }^{7} J o s a$ Andras County Teaching Hospital, Nyiregyhaza. ${ }^{8}$ Balassa Janos Tolna County Hospital, Szekszard. ${ }^{9}$ National Institute of Rheumatology and Physiotherapy, Budapest. ${ }^{10}$ Dept. of Pediatrics, University of Debrecen. ${ }^{11}$ Dept. of Pediatrics, University of Szeged, Hungary.

Published: 14 September 2011

\section{doi:10.1186/1546-0096-9-S1-P265}

Cite this article as: Derfalvi et al:: Age related clinical presentation and laboratory parameters in juvenile SLE: a Hungarian multicenter study. Pediatric Rheumatology 2011 9(Suppl 1):P265. 